\title{
Effect of Uncaria tomentosa extract on purinergic enzyme activities in lymphocytes of rats submitted to experimental adjuvant arthritis model
}

Lívia G. Castilhos' ${ }^{1}$, João F. P. Rezer ${ }^{1,2}$, Jader B. Ruchel ${ }^{1,2}$, Maria Luiza Thorstenberg ${ }^{1,2}$, Jeandre A. dos S. Jaques ${ }^{1,2}$, Josiane B. Schlemmer ${ }^{1,2}$, Pedro H. Doleski ${ }^{1}$, Mateus F. Rossato ${ }^{2}$, Mariane A. da Silva ${ }^{2}$, Emerson André Casalli ${ }^{3,4}$, Ritiel Corrêa da Cruz ${ }^{5}$, Juliano Ferreira ${ }^{2}$, Margareth L. Athayde ${ }^{5}$, Jamile F. Gonçalves ${ }^{1,2^{*}}$ and Daniela B. R. Leal ${ }^{1,2^{*}}$

\begin{abstract}
Background: Considering that adjuvant arthritis is an experimental model of arthritis widely used for preclinical testing of numerous anti-arthritic agents, which were taken by a large number of patients worldwide, it is of great interest to investigate the therapeutic action of compounds with anti-inflammatory properties, such as Uncaria tomentosa extract. Moreover, there are no studies demonstrating the effect of $U$. tomentosa on the metabolism of adenine nucleotides published so far. Thus, the purpose of the present study is to investigate the effects of $U$. tomentosa extract on E-NTPDase and E-ADA activities in lymphocytes of Complete Freund's Adjuvant (CFA) arthritis induced rats.

Methods: To evaluate the effect of $U$. tomentosa extract on the activity of E-NTPDase and ADA in lymphocytes, the rats were submitted to an experimental adjuvant arthritis model. Peripheral lymphocytes were isolated and E-NTPDase and E-ADA activities were determined. Data were analyzed by a one- or two-way ANOVA. Post hoc analyses were carried out by the Student-Newman-Keuls (SNK) Multiple Comparison Test.
\end{abstract}

Results: E-NTPDase activity was increased in arthritic untreated. Arthritic rats which received U. tomentosa extract, presented similar results to the control group. However, results obtained for adenosine hydrolysis by E-ADA were not altered in arthritic rats. U. tomentosa extract did not alter E-NTPDase and E-ADA activity in healthy animals.

Conclusions: The present investigation supports the hypothesis that the increased E-NTPDase activity verified in arthritic rats might be an attempt to maintain basal levels of ATP and ADP in the extracellular medium, since the arthritis induction causes tissue damage and, consequently, large amounts of ATP are released into this milieu. Also, it highlights the possibility to use $U$. tomentosa extract as an adjuvant to treat arthritis.

Keywords: Adjuvant arthritis, Uncaria tomentosa, lymphocytes, E-NTPDase, Adenosine deaminase

\section{Background}

Uncaria tomentosa (Willd.) DC. is a giant vine of the Rubiaceae family that grows in the Amazon rainforest and because of its curved thorns it is commonly known as 'cat's claw' or 'uña de gato'. This species has been extensively used among several Peruvian tribes for the

\footnotetext{
* Correspondence: jamilefabbrin@yahoo.com.br; dbitencourtrosaleal@gmail.com 'Departamento de Microbiologia e Parasitologia, Centro de Ciências da Saúde, Universidade Federal deSanta Maria, Av. Roraima, Prédio 20 - Sala 4102, 97105-900 Santa Maria, RS, Brazil

Full list of author information is available at the end of the article
}

treatment of many diseases, such as arthritis and other inflammatory disorders [1]. Its active ingredients appear to be polyphenols (flavonoids, proanthocyanidins, and tannins), sterols, and alkaloids [2]. Among numerous $U$. tomentosa compounds, the mitraphylline is considered the major alkaloid present in this plant and it might be, at least partially, responsible for the anti-inflammatory activity of Uncaria bark extracts [3]. In most studies, its anti-inflammatory activity has been uniquely attributed to tetracyclic and pentacyclic oxindole alkaloids. However, currently available pharmacological data have indicated

\section{Ciomed Central}

(c) 2015 Castilhos et al. This is an Open Access article distributed under the terms of the Creative Commons Attribution License (http://creativecommons.org/licenses/by/4.0), which permits unrestricted use, distribution, and reproduction in any medium, provided the original work is properly credited. The Creative Commons Public Domain Dedication waiver (http:// creativecommons.org/publicdomain/zero/1.0/) applies to the data made available in this article, unless otherwise stated. 
that this biological activity is due to the synergistic action of several compounds present in this species [4-8].

Arthritis is a systemic inflammatory disease characterized by joint pain, stiffness and swelling due to synovial inflammation, as well as fatigue and limitation in physical function, and increased morbidity and mortality [9]. It is a debilitating condition occurring at any age, peaking between the ages of 35 and 50 years and affecting around $1 \%$ of the world population [10]. Adjuvant-induced arthritis is a commonly used model of inflammatory arthritis, which has an incidence of approximately $90 \%$, making it an ideal model to investigate arthritic changes and to evaluate compounds that may be useful for arthritis treatment $[11,12]$. During the inflammatory process in arthritis, the immune and inflammatory responses are active, and it is well known that an imbalance between pro- and anti-inflammatory cytokine activities favors the induction of autoimmunity, chronic inflammation and thereby joint damage [13].

Extracellular nucleotides are essential molecules for the onset and maintenance of inflammatory reactions, whereas they are important signaling molecules [14]. The purinergic signaling system plays an important role in modulating the inflammatory and immune responses by extracellular biomolecules, such as adenine nucleotides (ATP, ADP and AMP) and their derived nucleoside adenosine [15]. There is evidence indicating that high extracellular ATP levels act through specific cell surface receptors as pro-inflammatory agents that potentiate the release of pro-inflammatory cytokines [16] from activated lymphocytes [17].

Extracellular ATP and adenosine levels, as well as the subsequent purinergic signaling, can be physiologically and dynamically controlled by the action of enzymes expressed in immune cells [16]. E-NTPDase (CD39) is the membrane-bound enzyme involved in the breakdown of ATP and ADP to AMP, which is sequentially hydrolyzed by $5^{\prime}$-nucleotidase to adenosine [18-20]. CD39 was first described as a B lymphocyte activation marker [21]. In leucocytes, its modulatory effects in cytokines expression, inflammatory response, cell-cell adhesion, as well as cell proliferation, via modulation of ATP levels in the pericellular milieu has been demonstrated [4-7]. According to Barankiewicz et al. [22], the presence of CD73 on the external surface of $B$ cells is also related to $B$ cell development.

E-ADA is another important enzyme that catalyzes the irreversible deamination of adenosine and 2'-deoxyadenosine to inosine and 2'-deoxyinosine, respectively. Therefore it contributes to the removal of adenosine from the extracellular compartment [23]. This enzyme has fundamental biological role in the proliferation and differentiation of lymphoid cells, particularly $\mathrm{T}$ lymphocytes, and maturation of monocytes [24], performing an important function in the immune system and inflammatory processes [25].
Considering that adjuvant arthritis is an experimental model of arthritis widely used for preclinical testing of numerous anti-arthritic agents, which are either under preclinical or clinical investigation, it is of clinical interest to investigate the therapeutic action of compounds with anti-inflammatory properties, such as Uncaria tomentosa extract. Moreover, to our knowledge, the current study is the first one evaluating the effect of $U$. tomentosa on the metabolism of adenine nucleotides. Thus, it is relevant to investigate its effects on the activity of E-NTPDase and E-ADA in lymphocytes of rats with Complete Freund's Adjuvant (CFA)-induced arthritis.

\section{Methods \\ Chemicals}

Complete Freund's Adjuvant (CFA - 0.6 \% suspension of heat-killed Mycobacterium tuberculosis in liquid paraffin), 5-(N,N-diethylamino) pentyl-3,4,5-trimethoxybenzoate (TMB), hexadecyltrimethylammonium bromide (HTAB), the substrates ATP, ADP, adenosine, as well as Trizma base, Coomassie Brilliant Blue $\mathrm{G}$ and bovine serum albumin were obtained from Sigma Chemical Co (St. Louis, $\mathrm{MO}$, USA) and $\mathrm{K}_{2} \mathrm{HPO}_{4}$, from Reagen. The acetonitrile and acetic acid were obtained from JTBarker, the triethylamine and polyamide from Fluka and ethanol from Vetec. All the other chemicals used in this experiment were of the highest purity.

\section{Animals}

Twenty eight adult female Wistar rats (200-300 g) were used in this experiment. Animals were divided into four groups, namely, control (C); extract (E); arthritis (A); and arthritis along with extract $(A+E)$. Animals were kept on a 12-h light/12-h dark cycle, at a temperature of $22 \pm 2{ }^{\circ} \mathrm{C}$, with free access to food and water. The animals were handled according to the guidelines of the Committee on Brazilian Society of Animal Science Lab [26], in accordance with international guidelines. Furthermore, this investigation was approved by the Committee on the Use and Care of Laboratory Animals of our university (n. 125/2010(2)).

\section{Induction of arthritis}

To investigate the effect of the $U$. tomentosa extract over the inflammatory process, the adjuvant-induced arthritis model was used and described by Sauzem et al., [27]. Animals were slightly anesthetized with isoflurane and $100 \mu \mathrm{L}$ of Complete Freund Adjuvant (CFA - $0.6 \%$ suspension of heat-killed Mycobacterium tuberculosis in liquid paraffin) was injected into the right hind paw to induce arthritis.

\section{HPLC analysis of $U$. tomentosa extract}

Sample extraction was performed using a Unique ultrasound, model USC 5000A, $40 \mathrm{kHz}$. Chromatographic 
analyses were performed on the Agilent 1100 HPLC system and a Zorbax ${ }^{\circ}$ XDB C-18 column $(150 \mathrm{~mm} \times 4.6 \mathrm{~mm}$, 3.5 _m Agilent) at $15{ }^{\circ} \mathrm{C}$. Samples $(80 \mathrm{mg})$ were diluted in $60 \%$ ethanol $(10 \mathrm{~mL})$ and subjected to sonication $(20 \mathrm{~min}$ at $30{ }^{\circ} \mathrm{C}$ ). Following this step, $2 \mathrm{~mL}$ of sample were passed through a column containing $200 \mathrm{mg}$ of polyamide, and the eluate was injected into an HPLC system. Separation was achieved using gradient elution of water $(0.2 \%$ acetic acid) adjusted to $\mathrm{pH} 6.9$ with triethylamine (A) and acetonitrile (B) at a flow rate of $0.8 \mathrm{~mL} / \mathrm{min}$, detection was performed at $245 \mathrm{~nm}$, and the concentrations of alkaloids were calculated as previously described [28].

\section{Treatment with $U$. tomentosa extract}

The treatment of animals with extract began 15 days after induction of arthritis by CFA. The $U$. tomentosa root dry extract was donated by Herbarium Botanical Laboratory, PR-Brazil, lot number 991260 . The organoleptic, physicochemical and microbiological characteristics were within quality standards; according to the Certificate of Analysis number 3301/11 presented by supplier. The extract was prepared daily with distilled water as vehicle and administered to the groups $\mathrm{E}$ and $\mathrm{A}+\mathrm{E}$ by gavage twice a day at the dose of $150 \mathrm{mg} / \mathrm{kg}$ for 45 days, mimicking the Unha de Gato ${ }^{\circ}$ phytotherapeutic from Herbarium Botanical Laboratory, indicated for treatment of patients with arthritis. Groups C and A received only distilled water in the same condition.

\section{Evidences of arthritis induction}

Evidence of arthritis induction as mechanical sensitivity and paw thickness of each rat were evaluated briefly before induction of arthritis by CFA, and then 15 days after induction. Increased mechanical sensitivity and paw thickness were considered as markers of the inflammatory process. Moreover, these measurements were made 45 days after $U$. tomentosa treatment to observe the effect of $U$. tomentosa on the inflammatory process. To observe the development of edema, animals were held and the right hind paw thickness was measured using a digital caliper [29]. Additionally, increased paw thickness was considered as formation of edema. Mechanical allodynia was evaluated using the up-and-down method, described by Dixon [30], using von Frey filaments. Briefly, rats were placed in cages with a wire mesh bottom which allowed full access to the paws. The paw was touched with 1 of a series of 7 von Frey hairs with logarithmic increments $(6,8,10,15,26,60$ and 100). Von Frey hairs were applied perpendicularly to the plantar surface with sufficient force to cause slight buckling against the paw, and held for approximately $2-4 \mathrm{sec}$. Stimuli were presented at intervals of several seconds, allowing for apparent resolution of any behavioral responses to previous stimuli. To evaluate neutrophil infiltration, mieloperoxidase activity
(MPO) was evaluated in paw skin sample, as previously described [31]. Briefly, sample was homogenized in acetate buffer $(80 \mathrm{mM}, \mathrm{pH} 5.5)$ containing $0.5 \%$ HTAB and centrifuged at $16.000 \mathrm{xg}$ during $20 \mathrm{~min}$ at $4{ }^{\circ} \mathrm{C}$. After, $10 \mu \mathrm{L}$ of supernatant were added to $200 \mu \mathrm{L}$ of acetate buffer and $20 \mu \mathrm{L}$ of TMB $(18.4 \mathrm{mM})$ and incubated at $37^{\circ} \mathrm{C}$ for $3 \mathrm{~min}$. To stop the reaction, the microplates were taken to the ice bath and $30 \mu \mathrm{L}$ of acetic acid were added. The color formed was assessed at $630 \mathrm{~nm}$ and the results were expressed as optical density per $\mathrm{mg}$ of tissue $(\mathrm{OD} / \mathrm{mg}$ tissue).

\section{Isolation of lymphocytes from blood}

Rats were anesthetized with isoflurane and blood was collected by cardiac puncture. Blood was collected with $7.2 \mathrm{mg}$ dipotassium EDTA as anticoagulant and lymphocyte-rich mononuclear cell were isolated from blood collected with Ethylenediamine tetra acetic acid (EDTA) and separated on Ficoll-Histopaque density [32]. The percentage of lymphocytes was superior to $93 \%$, as previously described [33]. The integrity of lymphocytes preparation was confirmed by determining the lactate dehydrogenase (LDH) activity in intact and disrupted lymphocytes using the kinetic method of the Labquest apparatus (Diagnostics Gold Analyzer). The procedure was repeated before and after the incubation period. The protocol was carried out according to the manufacturer's instructions. Triton X-100 (1\%, final concentration) was used to disrupt the lymphocytes preparation. The enzymatic activity is expressed as units per liter, and one unit (1U) corresponds to $1 \mu \mathrm{mol}$ of NADH formed per minute per liter. The resultant lymphocytes samples were used immediately for enzymatic assays.

\section{Protein determination}

Protein was measured by the Comassie Blue method according to Bradford [34] using serum albumin as standard.

\section{E-NTPDase activity determination}

E-NTPDase activity in lymphocytes was determined as previously described by Leal et al. [35], in which the reaction medium contained $0.5 \mathrm{mM} \mathrm{CaCl}_{2}, 120 \mathrm{mM} \mathrm{NaCl}, 5 \mathrm{mM}$ $\mathrm{KCl}, 60 \mathrm{mM}$ glucose and $50 \mathrm{mM}$ Tris- $\mathrm{HCl}$ buffer at $\mathrm{pH}$ 8.0, with a final volume of $200 \mu \mathrm{L}$. Twenty microliters of the intact mononuclear cells suspended in saline solution was added to the reaction medium (2-4 $\mu$ g of protein), and pre-incubated for $10 \mathrm{~min}$ at $37^{\circ} \mathrm{C}$; incubation proceeded for $70 \mathrm{~min}$. The reaction was initiated by the addition of substrate (ATP or ADP) at a final concentration of $2.0 \mathrm{mM}$ and stopped with $200 \mu \mathrm{L}$ of $10 \%$ trichloracetic acid (TCA). The released inorganic phosphate $(\mathrm{Pi})$ was assayed by a method previously described by Chan et al. [36] using malachite green as colorimetric reagent and $\mathrm{KH}_{2} \mathrm{PO}_{4}$ as standard. Controls were carried out by adding the enzyme preparation after TCA addition to correct for non-enzymatic nucleotide hydrolysis. All samples were 
run in triplicate and the specific activity is reported as $\mathrm{nmol}$ of Pi released $/ \mathrm{min} / \mathrm{mg}$ of protein.

\section{Adenosine deaminase activity determination (ADA)}

ADA activity in lymphocytes was measured by the method of Giusti and Galanti [37], which is based on the direct measurement of ammonia produced when ADA acts in excess of adenosine. Briefly, $25 \mu \mathrm{L}$ of lymphocytes reacted with $21 \mathrm{mM}$ of the substrate (adenosine), $\mathrm{pH} 6.5$, and incubation was carried out for $1 \mathrm{~h}$ at $37^{\circ} \mathrm{C}$. The reaction was stopped by adding $106 \mathrm{mM}$ and $167.8 \mathrm{mM}$ sodium nitroprussiate and hypochlorite solution. Ammonium sulfate $75 \mu \mathrm{M}$ was used as ammonium standard. All the experiments were performed in triplicate and the values were expressed in U/L for ADA activity. One unit (1U) of ADA is defined as the amount of enzyme required to release $1 \mathrm{mmol}$ of ammonia per minute from adenosine at standard assay conditions.

\section{Separation of blood serum}

Rats were anesthetized with isoflurane and blood was collected by cardiac puncture. The blood samples were collected in tubes without anticoagulant and after the clot formation were centrifuged at $1400 \mathrm{~g}$ for $15 \mathrm{~min}$ at room temperature. The resultant serum samples were aliquoted in microtubes and kept on ice until the purines quantification.

\section{Purine level measurement}

The quantitative determination of adenine nucleotides and adenosine levels were performed in serum by HPLC. At first, proteins were denatured by the addition of $0.6 \mathrm{~mol} / \mathrm{L}$ of percloric acid. Then, all samples were centrifuged $(14,000 \times \mathrm{g}$ for $10 \mathrm{~min})$. The obtained supernatants were neutralized with $4 \mathrm{~N} \mathrm{KOH}$ and clarified with a second centrifugation $(14,000 \times \mathrm{g}$ for $15 \mathrm{~min})$. Aliquots of $40 \mu \mathrm{L}$ were applied to a reversed-phase HPLC system using a $25 \mathrm{~cm}$ C18 Shimadzu column (Shimadzu, Japan) at $260 \mathrm{~nm}$ with a mobile phase containing $60 \mathrm{mM} \mathrm{KH}_{2} \mathrm{PO}_{4}, 5 \mathrm{mM}$ tetrabutylammonium chloride, $\mathrm{pH}$ 6.0, in $30 \%$ methanol according to a method previously described by Voelter [38]. The peaks of purines (ATP, ADP, AMP and adenosine) were identified by their retention times and quantified by comparison with standards. Results are expressed as nmoles of the different compounds per $\mathrm{mL}$ of serum.

\section{Statistical analysis}

Data were analyzed by a one- or two-way ANOVA. Post hoc analyses were carried out by the Student-NewmanKeuls (SNK) Multiple Comparison Test. Purine level were log-transformed to achieve normal distribution of data. A probability of $P<0.05$ was considered significant. All data are expressed as mean \pm Standard Error of the Mean (SEM).

\section{Results}

Evidences of arthritis induction and effect of $U$. tomentosa extract

As shown in Fig. 1, CFA injection was able to increase mechanical sensitivity (mechanical allodynia) (Fig. 1a), paw thickness (Fig. 1b) and MPO activity (Fig. 1c) in $72.4 \%, 120.1 \%$ and $35.3 \%$, respectively, when compared to baseline, characterizing an arthritic process. After 45 days of treatment, $U$. tomentosa extract was able to partially reverse the mechanical allodynia $(23.1 \pm 2.7 \%$, $P<0.01)$, edema $(21.6 \pm 5.7 \%, P<0.001)$ and MPO activity $(35.5 \pm 5.2 \%, P<0.01)$.

\section{HPLC analysis of $U$. tomentosa extract}

The HPLC analysis of the $U$. tomentosa root dry extract used in the present investigation is presented in Fig. 2. The extract has a content of $0.49 \%$ of pentaciclic and tetraciclic oxindole alkaloids. The concentrations of each one were as follows: uncarine D - $0.05 \%$, uncarine F - $0.01 \%$, mytraphyilline $-0.12 \%$, rhynchophylline $-0.07 \%$, isomytraphylline- $0.05 \%$, uncarine $\mathrm{C}-0.10 \%$, isorhyncophylline $-0.05 \%$ and uncarine $\mathrm{E}-0.04 \%$.

\section{E-NTPDase activity determination}

Figure 3 shows the effect of oral administration of $U$. tomentosa extract on ATP and ADP hydrolysis by ENTPDase in lymphocytes of rats submitted to an experimental adjuvant arthritis model. Results of lymphocytes E-NTPDase activity with ATP as substrate are shown in Fig. 3a. The hydrolysis of ATP was altered in rats with arthritis (A) $(65.5 \mathrm{nmol}$ of $\mathrm{Pi} / \mathrm{min} / \mathrm{mg}$ of protein; $\mathrm{SEM}=$ 4.8; $n=7 ; P<0.05)$, demonstrating that ATP hydrolysis was increased by $25.7 \%$ when compared to the control group (C) (48.7 $\mathrm{nmol}$ of $\mathrm{Pi} / \mathrm{min} / \mathrm{mg}$ of protein; $\mathrm{SEM}=3.2$; $n=7 ; P<0.05)$ and by $28.2 \%$ when compared to the extract group (E) $(47 \mathrm{nmol}$ of $\mathrm{Pi} / \mathrm{min} / \mathrm{mg}$ of protein; $\mathrm{SEM}=$ 4.9; $n=7 ; P<0.05)$. However, two-way ANOVA showed no significant interaction $[\mathrm{F}(1,15)=1.458 ; p=0.246 ; n=7]$ among the variables. In addition, results obtained for the lymphocytes E-NTPDase activity with ADP as substrate are shown in Fig. 3b, where the ADP hydrolysis was also increased by $32.5 \%$ in the A group $(62.4 \mathrm{nmol} \mathrm{Pi} / \mathrm{min} / \mathrm{mg}$; $\mathrm{SEM}=7.6 ; n=7 ; P<0.05)$ when compared to $C(42.1 \mathrm{nmol}$ of $\mathrm{Pi} / \mathrm{min} / \mathrm{mg}$ of protein; $\mathrm{SEM}=3.0 ; n=7 ; P<0.05)$, in $34.3 \%$ when compared to E group $(41.0 \mathrm{nmol}$ of $\mathrm{Pi} / \mathrm{min} /$ mg of protein; $\mathrm{SEM}=2.9 ; n=7 ; P<0.05)$ and in $22 \%$ when compared to A + E group (48.7 $\mathrm{nmol}$ of $\mathrm{Pi} / \mathrm{min} / \mathrm{mg}$ of protein; $\mathrm{SEM}=2.7 ; n=7 ; P<0.05)$. Two-way ANOVA showed no significant interaction $[\mathrm{F}(1,13)=2.606 ; p=0.130 ; n=7]$. The results of lymphocytes E-NTPDase activity in the group $\mathrm{E}$ with both ATP $(47.0 \mathrm{nmol}$ of $\mathrm{Pi} / \mathrm{min} / \mathrm{mg}$ of protein; SEM $=4.9 ; n=7 ; P<0.05)$ and ADP (41.0 nmol of $\mathrm{Pi} / \mathrm{min} / \mathrm{mg}$ of protein; $\mathrm{SEM}=2.9 ; n=7 ; P<0.05)$ as substrate were similar to ATP $(48.7 \mathrm{nmol}$ of $\mathrm{Pi} / \mathrm{min} / \mathrm{mg}$ of 

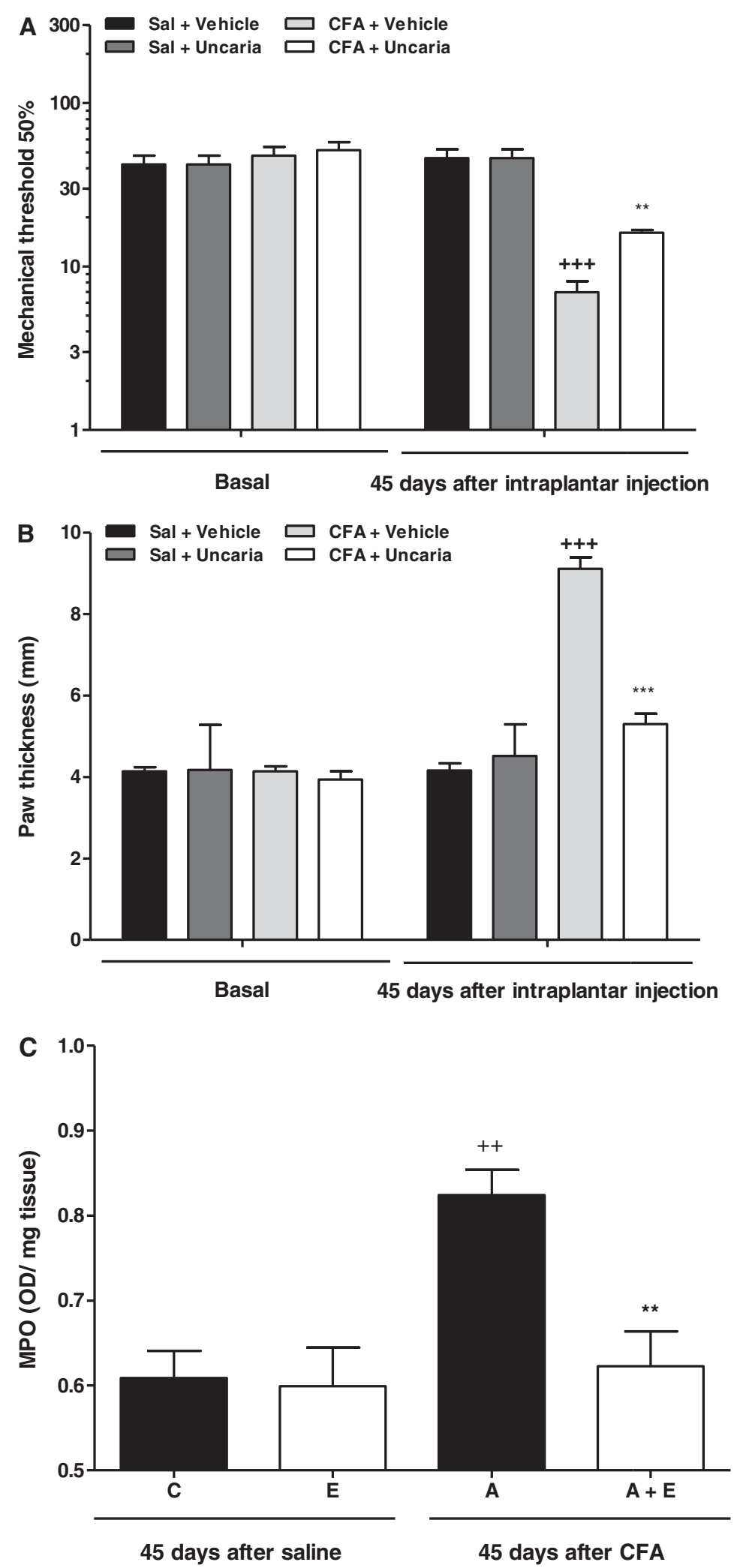

Fig. 1 Evidence of arthritis induction and the effect of $U$. tomentosa treatment ( $150 \mathrm{mg} / \mathrm{kg}, 2$ times/day, v.o.) for 45 days on the inflammatory process induced by CFA. Mechanical sensitivity (a) and paw edema (b) before (Basal) and after intraplantar injection (saline or CFA), as well as (c) MPO activity. " + " and "*" represent statistical difference in relation to control and arthritic group, respectively $(P<0.05)$. Bars represent means \pm SEM. One Way ANOVA followed by Student Newman Keuls (SNK) 
protein; $\mathrm{SEM}=3.2 ; n=7 ; P<0.05)$ and ADP hydrolysis in control group $(42.1 \mathrm{nmol}$ of $\mathrm{Pi} / \mathrm{min} / \mathrm{mg}$ of protein; $\mathrm{SEM}=3.0 ; n=7 ; P<0.05)$, showing that in healthy rats the extract did not alter the E-NTPDase activity.

\section{Adenosine deaminase activity determination (ADA)}

Results obtained for adenosine hydrolysis by E-ADA are shown in Fig. 4. The adenosine hydrolysis was not altered. The groups showed no significant alterations in the E-ADA activity when adenosine was used as substrate. Two-way ANOVA showed no significant interaction $[\mathrm{F}(1,15)=1.572, p=0.229, n=7]$.

\section{Purine level measurement}

Purine levels in serum were measured by HPLC and were showed in Table 1. Levels of ATP, ADP, AMP and adenosine showed no significant alterations in the $\mathrm{A}$ group when compared to control. The levels of these nucleotides and nucleoside were also normal in the $\mathrm{E}$ group when compared to control, showing that the extract did not interfere in the purine level. However, in the A $+\mathrm{E}$ group, the level of ATP was decreased by $14.4 \%$ when compared to $\mathrm{C}$ and $\mathrm{A}$ groups and in $12.7 \%$ comparing to $\mathrm{E}$ group, whereas ADP levels were increase by $7.2 \%, 4.6 \%$ and $7.2 \%$ regarding to $\mathrm{C}, \mathrm{E}$, and $\mathrm{A}$ groups, respectively. The adenosine levels in in the $\mathrm{A}+\mathrm{E}$ group were also decreased by $17.8 \%$ in comparison to control.

\section{Discussion}

Experimental animal models of chronic diseases allow a better understanding of the physiopathological processes and also the evaluation of potential new therapies. Based on that, the model of arthritis induced by CFA in rats is widely used in the research of new therapies for chronic inflammatory arthropathies, such as rheumatoid arthritis [39]. Cat's claw (Uncaria tomentosa) has been widely used for the treatment of arthritis, rheumatism and other inflammatory diseases due to its well known anti-inflammatory effects [39-41]. This plant contains a series of secondary metabolites, such as oxindole alkaloids, polyphenols (flavonoids, proanthocyanidins, tannins), quinovic acid glycosides, polyhydroxylated triterpenes and saponins, but its anti-inflammatory activity is related to more than one metabolite acting in synergy $[4,5,42,43]$. Here, the HPLC analysis revealed that mitraphylline was the preponderant alkaloid present in the $U$. tomentosa extract used for this research. In fact, Rojas-Duran et al. [3] reported that the major alkaloid of $U$. tomentosa was mytraphylline and evaluated its biological relevance demonstrating that it was able to impair the liberation of the interleukins $1 \alpha, 1 \beta, 4,17$ and TNF- $\alpha$, key molecules involved in inflammatory responses. Since the inflammatory action is closely associated to the immune process [44], benefits of this plant to the immune system, such as in purinergic signaling present in lymphocytes, could also be expressed as an anti-inflammatory action. However, a direct relationship between the components of this plant and purine nucleotides has not yet been reported in the literature.

In the present study, we induced arthritis in animals by the use of CFA and the inflammatory process was confirmed through the measurement of increased paw thickness, mechanical thresholds and MPO activity (neutrophil marker), which characterizes an arthritic process. After that, we analyzed if $U$. tomentosa extract would be able to reverse this process, and it showed to be partially effective. Similar results were also observed with carrageenaninduced paw edema demonstrating that both hydro-

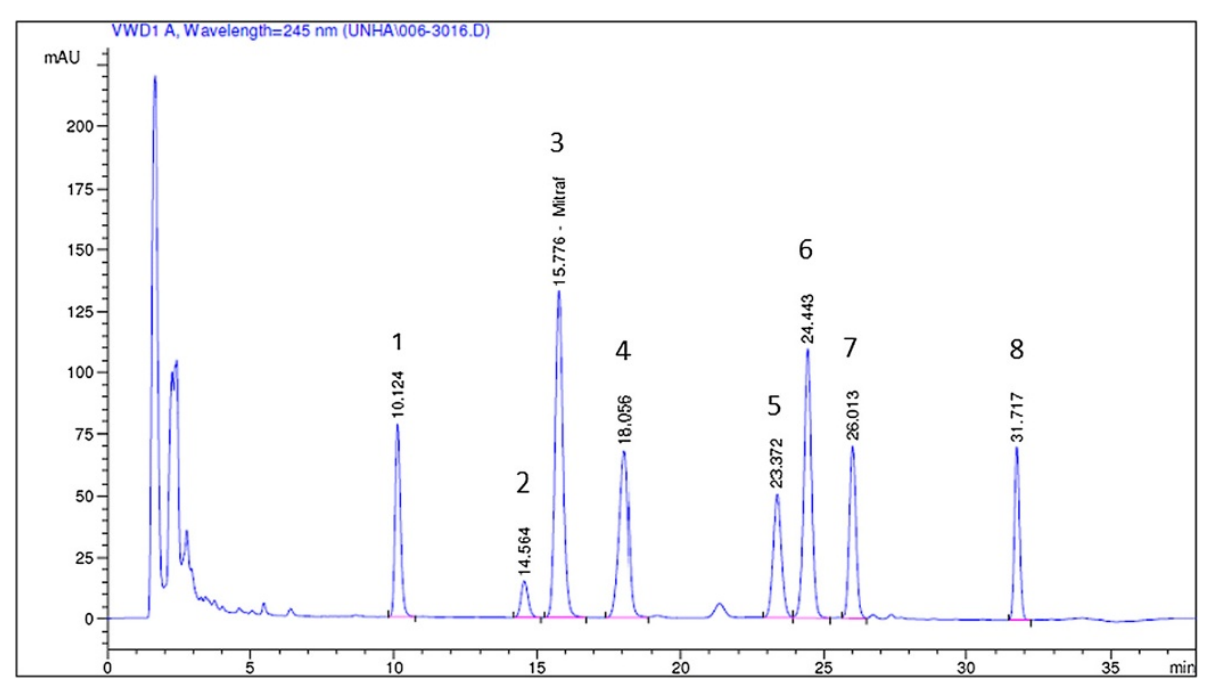

Fig. 2 HPLC fingerprint analysis of root dry extract from U. tomentosa. Uncarine D (1), uncarine F (2), mytraphyilline (3), rhynchophylline (4), isomytraphylline (5), uncarine C (6), isorhyncophylline (7) and uncarine E (8) 


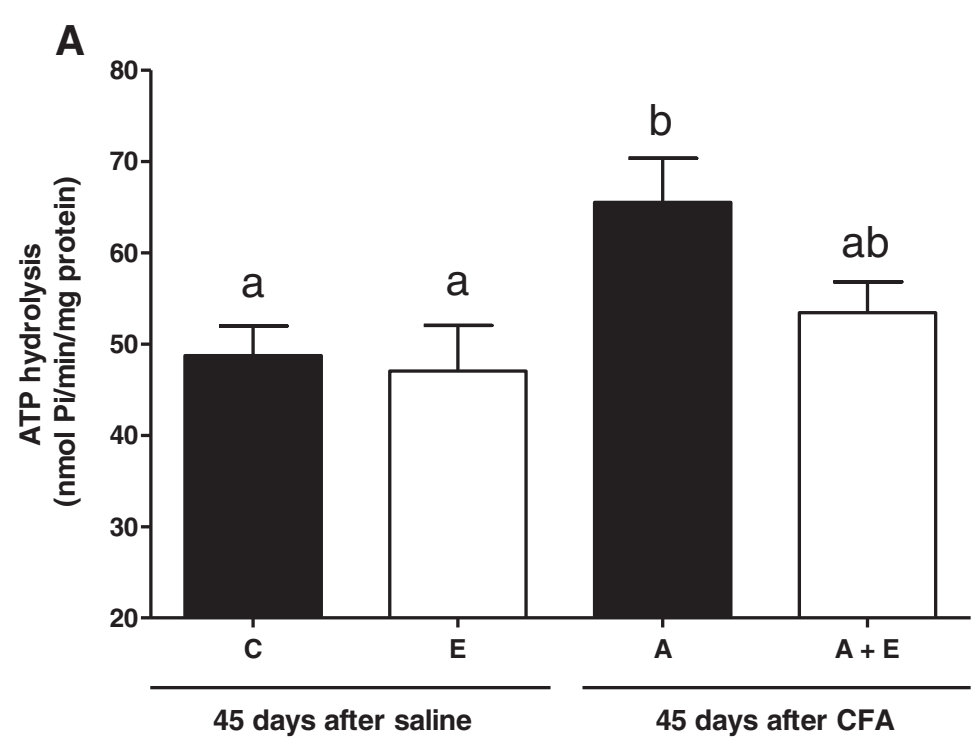

B

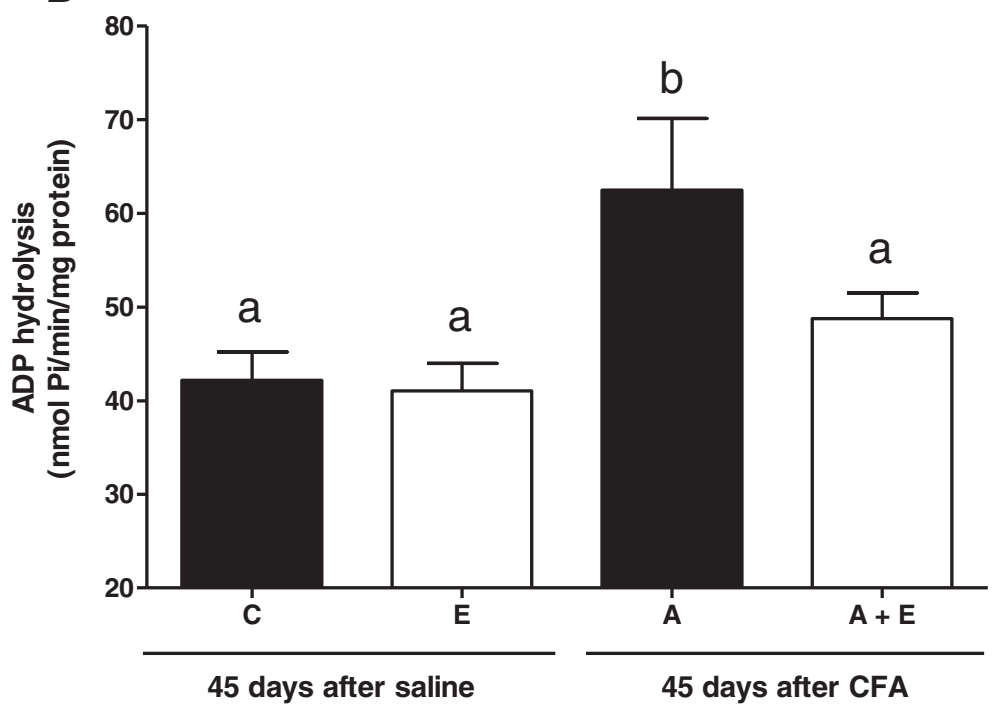

Fig. 3 ATP (a) and ADP (b) hydrolysis in lymphocytes of Complete Freund's Adjuvant (CFA)- induced arthritis rats and treated for 45 days with Uncaria tomentosa extract in the dose of $150 \mathrm{mg} / \mathrm{kg}, 2$ times/day. Enzyme specific activities are reported as $\mathrm{nmol}$ of Pi released/min/mg of protein. Groups: C (control), E (extract), A (arthritis) and A + E (arthritis + extract). Bars represent mean \pm S.E.M. ( $\left.{ }^{a, b}\right)$ Indicates a significant $P<0.05$, with $n=7$ (one-way ANOVA-Newman-Keuls Multiple Comparison Test)

alcoholic and aqueous extract have anti-inflammatory activity by decreasing the carrageenan-induced increase in paw volume when compared with control rats [44-46]. Human tests with $U$. tomentosa were carried out in patients with osteoarthritis and rheumatoid arthritis and demonstrated that it was able to reduce pain, morning stiffness and swelling joints [47-49].

Extensive tissue damage in inflammatory processes may lead to a significant increase in the levels of purine and pyrimidine nucleotides within the involved sites, probably contributing to the amplification of the inflammatory reaction [50]. Extracellular ATP can act as a damage-associated molecular pattern, given that it is normally confined to intracellular sites but can be released at high levels following cell lysis, infection, or via regulated efflux. ATP released into the extracellular space can modulate the immune response through its capacity to bind and activate multiple nucleotide receptor family members $[51,52]$. In addition, the purinergic system is also composed by a complex of ectoenzymes including E-NTPDase and E-ADA that are responsible for extracellular nucleotide hydrolysis.

The results of the present study showed an increased E-NTPDase activity in rats with arthritis when compared to control animals corroborating with Becker et al. [53] 


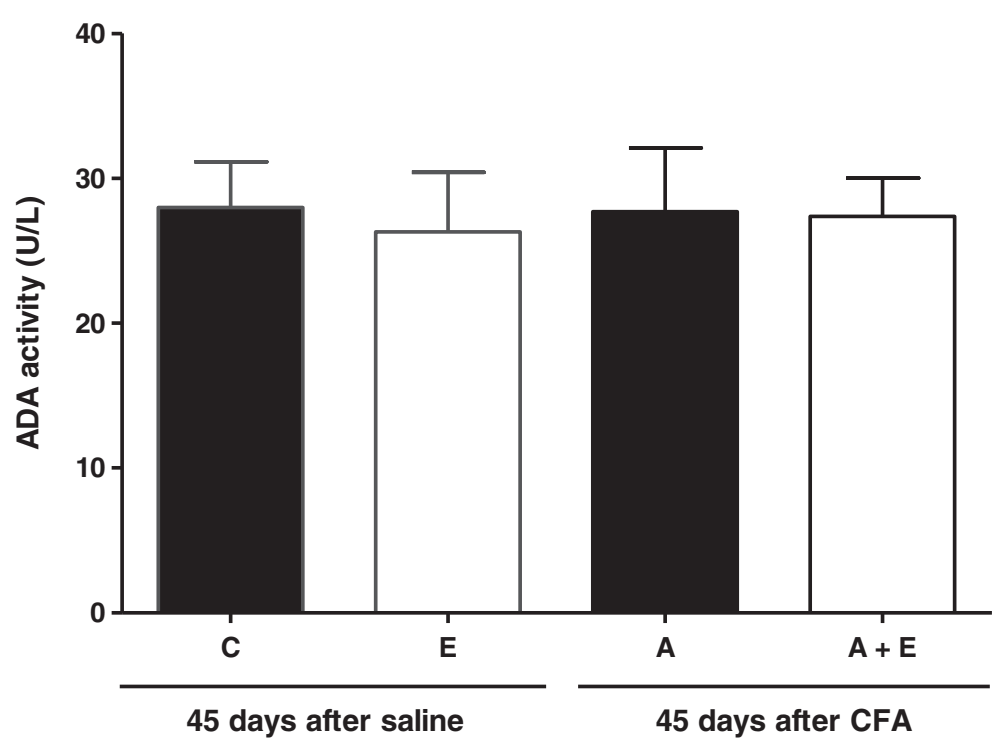

Fig. 4 Adenosine hydrolysis in lymphocytes of Complete Freund's Adjuvant (CFA)-induced arthritis rats and treated for 45 days with Uncaria tomentosa extract in the dose of $150 \mathrm{mg} / \mathrm{kg}, 2$ times/day. Enzyme activities are reported as U/L. Groups: C (control), E (extract), A (arthritis) and A + E (arthritis + extract). Bars represent mean \pm S.E.M. ( ${ }^{a}$, $)$ Indicates a significant $P<0.05$, with $n=7$ (one-way ANOVA-Newman-Keuls Multiple Comparison Test)

which found increased E-NTPDase activity in platelets of patients with arthritis. According to a study previously published by our research group, the E-NTPDase activity (both ATP and ADP substrate) in lymphocytes was also altered in patients with RA. The ATP hydrolysis presented a two-fold increase, while ADP hydrolysis was $80 \%$ increased when compared to the control group. [54]. Moreover, many other studies have shown that the E-NTPDase and E-ADA have significant roles in immune response. Alterations in their activities have been observed in some autoimmune diseases such as multiple sclerosis, lupus and diabetes [55-57]. Increased activity of E-NTPDase leads to increased ATP and ADP hydrolysis and, as a compensatory mechanism, leads to the maintenance of their appropriate levels, since high concentrations of ATP in the extracellular medium activate the proinflammatory purinergic P2X7 receptors and contributes to tissue damage and inflammation [58].
Since these enzymes act in a cascade, we can suggest that the $5^{\prime}$-nucleotidase activity in arthritic rats could be also increased, resulting in a greater amount of adenosine in the extracellular medium to compensate the proinflammatory effects of ATP. However, in these arthritic animals, the levels of ATP, ADP, AMP and adenosine are normal in the extracellular medium as well as E-ADA activity. We can assume that adenosine is being produced in excess by the supposed increased activity of $5^{\prime}$ nucleotidase. This adenosine could be binding to specific receptors expressed on the cell surface exercising its antiinflammatory function and maintaining the levels of adenosine normal on extracellular medium. Thus, adenosine acts as a negative feedback signal to counteract ATP-mediated immune stimulation, preventing uncontrolled inflammation and decreasing the collateral damage to healthy tissues [59]. The anti-inflammatory properties of $U$. tomentosa have been described, hence we evaluated the effect of the

Table 1 Purine levels in arthritic rats serum and treated for 45 days with Uncaria tomentosa extract

\begin{tabular}{|c|c|c|c|c|}
\hline & $\begin{array}{l}\text { C } \\
(\log \text { of } \mathrm{nmol} / \mathrm{ml})\end{array}$ & $\begin{array}{l}\text { E } \\
(\log \text { of } n m o l / m l)\end{array}$ & $\begin{array}{l}\text { A } \\
\text { (log of } n m o l / m l)\end{array}$ & $\begin{array}{l}A+E \\
(\log \text { of } n m o l / m l)\end{array}$ \\
\hline$\overline{\text { ATP }}$ & $1.04 \pm 0.003^{\mathrm{a}}$ & $1.02 \pm 0.01^{\mathrm{a}}$ & $1.04 \pm 0.02^{\mathrm{a}}$ & $0.89 \pm 0.01^{b}$ \\
\hline ADP & $1.25 \pm 0.002^{\mathrm{a}}$ & $1.28 \pm 0.01^{\mathrm{a}}$ & $1.25 \pm 0.01^{\mathrm{a}}$ & $1.34 \pm 0.001^{b}$ \\
\hline AMP & $1.00 \pm 0.005^{a}$ & $1.05 \pm 0.008^{a}$ & $1.04 \pm 0.008^{a}$ & $1.02 \pm 0.02^{\mathrm{a}}$ \\
\hline Adenosine & $1.35 \pm 0.001^{\mathrm{a}}$ & $1.29 \pm 0.02^{\mathrm{ab}}$ & $1.33 \pm 0.01^{\mathrm{ab}}$ & $1.11 \pm 0.08^{b}$ \\
\hline
\end{tabular}

Adenine nucleotides and adenosine levels measurement in serum of Complete Freund's Adjuvant (CFA)-induced arthritis rats and treated for 45 days with Uncaria tomentosa extract ( $150 \mathrm{mg} / \mathrm{kg} ; 2$ times/day). Purine levels measurement were log-transformed and are reported as log of $\mathrm{nmol} / \mathrm{ml}$. Groups: $\mathrm{C}$ (control), E (extract), A (arthritis) and A + E (arthritis + extract). Bars represent mean \pm S.E.M

$\left({ }^{\mathrm{a}, \mathrm{b}}\right)$ Indicates difference among the groups, $P<0.05$ with $\mathrm{n}=7$ (two-way ANOVA-Newman-Keuls Multiple Comparison Test) 
$U$. tomentosa dry extract on the metabolism of adenine nucleotides. In healthy animals treated with the extract, the activities of E-NTPDase and E-ADA remained at basal levels, what was also confirmed by serum purine levels, which were in normal concentration in the extracellular medium.

In arthritic rats treated with $U$. tomentosa dry extract, the increase on the E-NTPDase activity was prevented, while the purine levels on serum showed decreased ATP levels and increased ADP levels. It seems that low-level purinergic signaling induced by nucleotides at decreased concentrations, modulates ongoing inflammatory and immune responses by P2 receptors [60]. At low concentration, extracellular ATP possesses affinity for P2Y receptor subtype on the surfaces of lymphocytes. These purinergic receptors, when stimulated, develop a down-modulation of proinflammatory cytokines and stimulate the Th2 immune response, leading to the production of anti-inflammatory cytokines, protection from oxidative damage and downproduction of oxygen radicals in whole blood [16]. P2Y receptor signaling may therefore be an important stop signal to prevent excessive stimulation of inflammation and avoid conditions that might favor autoimmunity [61].

Among the various classes of chemical constituents found in $U$. tomentosa plant, oxindole alkaloids are regarded as the most important [43]. The alkaloid profile in $U$. tomentosa is important because of its pharmacological properties and because the pentacyclic oxindole alkaloids are directly associated with immunostimulatory properties [62]. The anti-inflammatory activity of traditional extracts made from $U$. tomentosa is well documented [63-65]. Mitraphylline is the most ubiquitous alkaloid being present in Uncaria species [62], being also the major compound present in our lot of $U$. tomentosa extract. Mitraphylline is considered as a new lead compound for the development of anti-inflammatory treatment, being the most chemical effective component and responsible for suppression of inflammation parameters. In one previous study, this compound inhibited around $50 \%$ of the release of pro-inflammatory interleukins, and its activity was similar to dexamethasone [3]. Therefore, these metabolites are certainly contributing to decrease the inflammatory process and regulate the purinergic signaling in this data.

Therefore, in this model, these metabolites probably contribute to decrease the inflammatory process and regulate the purinergic signaling. No changes were observed in the ADA activity, but a decrease in adenosine levels was observed in serum of the arthritic rats that received $U$. tomentosa extract. Corroborating our results, a study previously published by our research group [52] has showed that the level of adenosine in serum of RA patients was also decreased. In addition, ADP levels showed to be increased in this same group. It is possible that the adenylate kinase (EC 2.7.4.3) could be activated in an attempt to reconstitute the pool of ADP. As proposed by Yegutkin et al. [66], an opposite pathway could lead to the recovery of adenine nucleotides, since adenylate kinase was identified as another key player in the metabolism of circulating ADP. This extracellular ADP could be linking itself to P2Y receptor, the adenine-nucleotide-preferring receptors mainly responding to $\mathrm{ADP}$, and leading the antiinflammatory response.

\section{Conclusion}

In summary, our data demonstrate that the $U$. tomentosa extract was able to reduce partially the mechanical thresholds, paw thickness and MPO activity in a model of induced arthritis. In addition, the extract was able to prevent the increase on the E-NTPDase activity in lymphocytes of rats submitted to an experimental adjuvant arthritis model. In view of this, $U$. tomentosa extract had an actual effect against arthritis and for the first time we demonstrate that the purinergic signaling is involved in these responses.

\section{Abbreviations}

ADP: Adenosine diphosphate; AMP: Adenosine monophosphate; ATP: Adenosine triphosphate; CFA: Complete Freund's Adjuvant; MPO: Myeloperoxidase.

\section{Competing interests}

The authors declare that they have no competing interests.

\section{Authors' contributions}

LGC performed experiments and analyzed data. LGC and JAJ designed the study. MFR and MAS induced the arthritis; RCC did the extract HPLC analysis. JBR and MLT were responsible for animal's treatment. LGC, JFPR, JBS, PHD isolated the lymphocytes, determined the protein, E-NTPDase and ADA activity. EC measured the purine levels. JFG helps for data interpretation. JF, MLA and DBRL realized by read and approved the final manuscript. All authors read and approved the final manuscript.

\section{Acknowledgments}

The authors wish to thank the HERBARIUM Laboratório Botânico LTDA for supplyin $\mathrm{g}$ the extract used to perform the experiment. This study was supported by the Conselho Nacional de Desenvolvimento Científico e Tecnológico (CNPq), Fundação de Amparo à Pesquisa do Rio Grande do Sul (FAPERGS), Fundação Coordenação de Aperfeiçoamento de Pessoal de Nível Superior (CAPES) and PRONEX, Brazil.

\section{Author details}

'Departamento de Microbiologia e Parasitologia, Centro de Ciências da Saúde, Universidade Federal deSanta Maria, Av. Roraima, Prédio 20 - Sala 4102, 97105-900 Santa Maria, RS, Brazil. ²Departamento de Química, Centro de Ciências Naturais e Exatas, Universidade Federal de Santa Maria, Av. Roraima, 97105-900 Santa Maria, RS, Brazil. ${ }^{3}$ Departamento de Ciências Morfológicas, Instituto de Ciências Básicas da Saúde, UFRGS, Laboratório de Estudos Sobre as Alterações Celulares e Teciduais, Porto Alegre, RS, Brazil.

${ }^{4}$ Laboratório de Enzimologia Aplicada ao Sistema Purinérgico, Departamento de Bioquímica, Instituto deCiências Básicas da Saúde, UFRGS, Porto Alegre, RS, Brazil. ${ }^{5}$ Departamento de Farmácia Industrial, Universidade Federal de Santa Maria, Av. Roraima, 97105-900 Santa Maria, RS, Brazil.

Received: 14 April 2014 Accepted: 27 May 2015

Published online: 20 June 2015 


\section{References}

1. Reinhard KH. Uncaria tomentosa (Willd.) D.C.: Cat's claw, uña de gato, or saventaro. J Altern Complement Med. 1999;5:143-51.

2. Patidar A, Birla D, Patel V, Chaturvedi M, Manocha N. A review of on advantages of natural analgesics over conventional synthetic analgesics. Int J Pharm Life Sci. 2014;5:3534-9.

3. Rojas-Durana R, Gonza'lez-Aspajoa G, Ruiz-Martel C, Bourdy G, Doroteo-Ortega $\mathrm{VH}$, Alban-Castillo J, et al. Anti-inflammatory activity of Mitraphylline isolated from Uncaria tomentosa bark. J Ethnopharmacol. 2012;143:801-4.

4. Wagner $\mathrm{H}$, Kreutzkamp B, Jurcic K. Die Alkaloide von Uncaria tomentosa ihre phagozytosesteigernde wirkung. Planta Med. 1985;51:419-23.

5. Aquino R, De Simone F, Pizza C, Conti C, Stein ML. Plant Metabolites structure and in vitro antiviral activity of quinovic acid glycosides from Uncaria tomentosa and Guettarda platypoda. J Nat Prod. 1989;52:679-85.

6. Aquino R, Vicenzo F, Francesco S. Plant Metabolites. New compounds and anti inflamatory activity of Uncaria tomentosa. J Nat Prod. 1991;52:679-85.

7. Yoshimoto K, Sato H, Ohtake M, Laus G, Brössner D, Keplinger K. Alkaloids of Peruvian Uncaria tomentosa. Phytochemistry. 1997;45:855-60.

8. Falkiewicz B, Łukasiak J. Vilcacora [Uncaria tomentosa (Willd.) DC. and Uncaria guianensis (Aublet) Gmell.]_a review of published scientific literature. Case Rep Clin Pract Rev. 2001;2:305-16.

9. Choy EH, Panayi GS. Cytokine pathways and joint inflammation in rheumatoid arthritis. N Engl J Med. 2001;344:907-16.

10. MacGregor AJ, Silman AJ. Rheumatoid arthritis and other synovial disorders: Classification and epidemiology. In: Hochberg MC et al., editors. Rheumatology, vol. 1. London: Mosby Publications; 2004.

11. Bush KA, Kirkham BW, Walker JS. The in vivo effects of tumor necrosis factor blockade on the early cell mediated immune events and syndrome expression in rat adjuvant arthritis. Clin Exp Immunol. 2002;127:423-9.

12. Hegen M, Keith Jr JC, Collins M, Nickerson-Nutter CL. Utility of animal models for identification of potential therapeutics for rheumatoid arthritis. Ann Rheum Dis. 2008;67:1505-15.

13. lain BM, Georg S. Cytokines in the pathogenesis of rheumatoid arthritis. Nat Rev Immunol. 2007;7:429-42.

14. Luttikhuizen DT, Harmsen MC, de Leij LFMH, van Luyn MJA. Expression of P2 receptors at site of chronic inflammation. Cell Tissue Res. 2004;317:289-98.

15. Ralevic V, Burnstock $G$. Involvement of purinergic signaling in cardiovascular diseases. Drug News Perspect. 2003;16:133-40.

16. Bours M, Swennen E, Di Virgilio F, Cronstein BN, Dagnelie PC. Adenosine $5^{\prime}$ triphosphate and adenosine as endogenous signaling molecules in immunity and inflammation. Pharmacol Ther. 2006;112:358-404.

17. Langston H, Ke Y, Gewirtz A, Dombrowski K, Kapp J. Secretion of IL-2 and IFN-y, but not IL-4, by antigen-speci.c T cells requires extracellular ATP. J Immunol. 2003; 170:2962-70.

18. Robson SC, Sévigny J, Zimmermann H. The E-NTPDase family of ectonucleotidases: structure function relationships and pathophysiological significance. Purinergic Signal. 2006;2:409-30.

19. Zimmermann H, Mishra S, Shukla V, Langer D, Gampe K, Grimm I, et al. Ecto-nucleotidases, molecular properties and functional impact. An R Acad Nac Farm. 2007;73:537-66.

20. Yegutkin GG. Nucleotide and nucleoside converting ectoenzymes: important modulators of purinergic signalling cascade. Biochim Biophs Acta. 2008;1783:673-94.

21. Pulte E, Broekman M, Olson K, Drosopoulos JHF, Kizer JR, Islam N, et al. CD39/NTPDase-1 activity and expression in normal leucocytes. Thromb Res. 2007;121:309-17.

22. Barankiewicz J, Dosch HM, Cohen A. Extracellular nucleotide catabolism in human B and T lymphocytes. The source of adenosine production. J Biol Chem. 1988;263:7094-8.

23. Franco R, Casadó V, Ciruela F, Saura C, Canela El, Lluis C. Cell surface adenosine deaminase: much more than an ectoenzyme. Prog Neurobiol. 1997:52:283-94.

24. Bota A, Javier Gella F, Profilis C, Férard G, Hadjivassiliou AG, Hørder M, et al. Production and certification of an enzyme reference material for adenosine deaminase 1 (BCR 647). Clin Chim Acta. 2001;306:79-89.

25. Antonioli L, Fornai M, Colucci R, Ghisu N, Tuccori M, Del Tacca M, et al. Pharmacological modulation of adenosine system: novel options for treatment of inflammatory bowel diseases. Inflamm Bowel Dis. 2008; 14:566-74.

26. SBCAL. Sociedade Brasileira de Ciências em Animais de Laboratório. Brasil: Cuidado e Manejo de Animais de Laboratório; 2009.
27. Sauzem PD, Sant'Anna GS, Machado P, Duarte MM, Ferreira J, Mello CF, et al. Effect of 5-trifluoromethyl-4,5-dihydro-1H-pyrazoles on chronic inflammatory pain model in rats. Eur J Pharmacol. 2009;616:91-100.

28. Bertol G, Franco L, Oliveira BH. HPLC Analysis of Oxindole Alkaloids in Uncaria tomentosa: Sample Preparation and Analysis Optimisation by Factorial Design. Phytochem Anal. 2012:23:143-51.

29. Cao YQ, Mantyh PW, Carlson EJ, Gillespie A, Epstein CJ, Basbaum A. Primary afferent tachykinins are required to experience moderate to intense pain. Nature. 1998;392:390-3

30. Dixon WJ. Efficient analysis of experimental observations. Ann Rev Pharmacol Toxicol. 1980;20:441-62

31. Suzuki K, Ota H, Sasagawa S, Sakatani T, Fujikura T. Assay method for myeloperoxidase in human polymorphonuclear leukocytes. Anal Biochem. 1983;132:345-52.

32. Böyum A. Isolation of mononuclear cells and granulocytes from human blood. Isolation of monuclear cells by one centrifugation, and of granulocytes by combining centrifugation and sedimentation at $1 \mathrm{~g}$. Scand J Clin Lab Invest Suppl. 1968;97:77-89.

33. Jaques JA, Peres Rezer JF, Ruchel JB, Gutierres J, Bairros AV, Gomes Farias IL, et al. A method for isolation of rat lymphocyte-rich mononuclear cells from lung tissue useful for determination of nucleoside triphosphate diphosphohydrolase activity. Anal Biochem. 2011;410:34-9.

34. Bradford MM. A rapid and sensitive method for the quantitation of microgram quantities of protein utilizing the principle of protein-dye binding. Anal Biochem. 1976;72:248-54.

35. Leal DBR, Streher CA, Neu TN, Bitencourt FP, Leal CAM, Silva JEP, et al. Characterization of NTPDase (NTPDase1; ecto-apyrase; ecto-diphosphohydrolase; CD39; E.C. 3.6.1.5) activity in humans lymphocytes. Biochim Biophys Acta. 2005;1721:9-15.

36. Chan KM, Delfert D, Junger KD. A direct colorimetric assay for $\mathrm{Ca} 2+$ stimulated ATPase activity. Anal Biochem. 1986;157:375-80.

37. Giusti G, Galanti B. Colorimetric Method. In: Bergmeyer HU, editor. Methods of enzymatic analysis. Weinheim: Verlag Chemie; 1984. p. 315-23.

38. Voelter W, Zech K, Arnold P, Ludwig G. Determination of selected pyrimidines, purines and their metabolites in serum and urine by reverse-phase ion-pair chromatography. J Chromatogr. 1980;199:345-54.

39. Akesson C, Lindgren H, Pero RW, Leanderson T, Ivars F. Quinic acid is a biologically active component of the Uncaria tomentosa extract C-Med 100. Int Immunopharmacol. 2005;5:219-29.

40. Jurgensen S, Dalbó S, Angers P, Santos AR, Ribeiro do Valle RM. Involvement of $5-\mathrm{HT} 2$ receptors in the antinociceptive effect of Uncaria tomentosa. Pharmacol Biochem Behav. 2005;81:466-77.

41. Pilarski R, Zieliński H, Ciesiołka D, Gulewicz K. Antioxidant activity of ethanolic and aqueous extracts of Uncaria tomentosa (Willd.) DC. J Ethnopharmacol. 2006;104:18-23.

42. Aquino R, De Simone F, Pizza C, Vincieri F, Gacs BE. New polyhydroxylated triterpenes from Uncaria tomentosa. J Nat Prod. 1990:53:559-64.

43. Laus G, Brossner D, Keplinger K. Alkaloids of peruvian Uncaria tomentosa. Phytochemistry. 1997:45:855-60.

44. Aguilar $\mathrm{L}$, Rojas P, Marcelo A, Plaza A, Bauer R, Reininger E, et al. Anti-inflamatory activity of two extracts of Uncaria tomentosa (Rubiaceae). J Ethnopharmacol. 2002;81:271-6.

45. Joe B, Griffiths MM, Remmers EF, Wilder RL. Animal models of rheumatoid arthritis and related inflammation. Cur Rheumat R. 1999;1:139-48.

46. Keplinger K, Laus G, Wurm M, Dierich MP, Teppner H. Uncaria tomentosa (Wild). Ethnomedicinal Uses and new pharmacological, toxicological and botanical results. J Ethnopharmacol. 1999;64:23-34.

47. Castañeda O, León G, León D, Calvoh A, Chávez J, Escalante J, et al. Uña de Gato en Artritis Reumatóide: Estúdio doble cego, en comparación com placebo. Rev Peru Reumatol. 1998:4:15-21.

48. Piscoya J, Rodriguez Z, Bustamante SA, Okuhama NN, Miller MJ, Sandoval M. Efficacy and safety of freeze-dried cat's claw in osteoarthritis knee: mechanism of actions of the species Uncaria guianensis. Inflamm Res. 2001;50:442-8.

49. Mur E, Hartig F, Eibl G, Schirmer M. Randized double blind trial of an extract from the pentacyclic alkaloid-chemotype of Uncaria tomentosa for the treatment of rheumatoid arthritis. J Rheumatol. 2002:29:678-81.

50. Miyara M, Sakaguchi S. Natural regulatory T cells: mechanisms of suppression. Trends Mol Med. 2007;13:108-16.

51. la Sala A, Ferrari D, Di Virgilio F, Idzko M, Norgauer J, Girolomoni G. Alerting and tuning the immune response by extracellular nucleotides. J Leukoc Biol. 2003;73:339-43. 
52. Gordon JL. Extracellular ATP: effects, sources and fate. Biochem J. 1986;233:309-19.

53. Becker LV, Rosa CS, Souza VCG, Bagatini MD, Casali EA, Leal CAM, et al. Activities of enzymes that hydrolyze adenine nucleotides in platelets from patients with rheumatoid arthritis. Clin Biochem. 2010;43:1096-100.

54. Jaques JAS, Becker LV, Souza VCG, Leal CAM, Bertoldo TMD, Pinheiro KV, et al. Activities of enzymes that hydrolyze adenine nucleotides in lymphocytes from patients with rheumatoid arthritis. Cell Biochem Funct. 2013;31:395-9.

55. Loza MJ, Anderson AS, O'Rourke KS, Wood J, Khan IU. T-cell specific defect in expression of the NTPDase CD39 as a biomarker for lupus. Cell Immunol. 2011;271:110-7.

56. Schmatz R, Schetinger MR, Spanevello RM, Mazzanti CM, Stefanello N, Maldonado PA, et al. Effects of resveratrol on nucleotide degrading enzymes in streptozotocin-induced diabetic rats. Life Sci. 2009;84:345-50.

57. Spanevello RM, Mazzanti CM, Schmatz R, Thome G, Bagatini M, Correa M, et al. The activity and expression of NTPDase is altered in lymphocytes of multiple sclerosis patients. Clin Chim Acta. 2010;411:210-4.

58. Di Virgilio F. The P2Z purinoreceptor: intriguing role in immunity, inflammation and cell death. Immunol Today. 1995;16:524-8.

59. Gessi S, Varani K, Merighi S, Fogli E, Sacchetto V, Benini A, et al. Adenosine and lymphocyte regulation. Purinergic Signal. 2007;3:109-16.

60. Di Virgilio F, Ferrari D, Idzko M, Panther E, Norgauer J, La Sala A, et al. P2 receptors, and inflammation. Drug Devel R. 2003;59:171-4.

61. Di Virgilio F, Boeynaems JM, Robson SC. Extracellular nucleotides as negative modulators of immunity. Cur Op Pharmacol. 2009;9:507-13.

62. Heitzman ME, Neto CC, Winiarz E, Vaisberg AJ, Hammond GB. Ethnobotany, phytochemistry and pharmacology of Uncaria (Rubiaceae). Phytochemistry. 2005;66:5.

63. Erowele $\mathrm{Gl}$, Kalejaiye AO. Pharmacology and therapeutic uses of cat's claw. Am J Health Syst Pharm. 2009;66:992-5.

64. Urdanibia I, Estrada O, Ibarra C, Michelangeli F, Milano B, Taylor P. Anti-inflammatory and anti-tumour effects of two species of Cat's claw (Uncaria). Planta Med. 2013;79:PF11.

65. Urdanibia I, Estrada O, Ibarra C, Michelangeli F, Ruiz MC, Taylor P. Anti-inflammatory effects of different preparations of cat's claw. Planta Med. 2012;78:PI131.

66. Yegutkin GG, Henttinen T, Samburski SS, Spychala J, Jalkanen S. The evidence for two opposite, ATP-generating and ATP-consuming, extracellular pathways on endothelial and lymphoid cells. Biochem J. 2002;367:121-8.

\section{Submit your next manuscript to BioMed Central and take full advantage of:}

- Convenient online submission

- Thorough peer review

- No space constraints or color figure charges

- Immediate publication on acceptance

- Inclusion in PubMed, CAS, Scopus and Google Scholar

- Research which is freely available for redistribution 